Acta Universitatis Nicolai Copernici • Pedagogika XXX/2014

Nauki Humanistyczno-Społeczne • Zeszyt 422

DOI: http://dx.doi.org/10.12775/AUNC_PED.2014.003

Jerzy Król

PWSZ Chełm

\title{
BEZPIECZEŃSTWO WYCHOWANIA I EDUKacJI W SZWEGJI A ETYKa
}

\section{LEKCJA RELIGII A DEMOKRATYCZNE ZASADY WYCHOWANIA I EDUKACJI}

W polityce wychowawczej i edukacyjnej w Szwecji na pierwszy plan wysuwa się troskę o zachowanie i rozwój wartości demokratycznych. Wychowanie i edukacja są w służbie demokratycznej społeczności. Takie ustawienie programów wychowawczych i edukacyjnych ma strzec zarówno samą edukację oraz wychowanie, jak i całe życie społeczne przed niebezpieczeństwem indoktrynacji i konserwatyzmu. Oficjalnie z tego powodu w latach sześćdziesiątych XX wieku przedstawiciele radykalnych nurtów kulturowych (culture-radical) domagali się takiego tekstu instrukcji religijnej, w którym chrześcijańska doktryna nie byłaby przedstawiana jako prawda. Zwłaszcza w pierwszej połowie lat sześćdziesiątych religijne zaangażowanie szkoły było mocno krytykowane przez radykalne kręgi kulturowe zarzucające szkole, że na przekór zasadom obiektywności prowadzi propagandę na rzecz wiary chrześcijańskiej. Interesujący był fakt, że sprzeciw w stosunku do nauczania religii $\mathrm{w}$ szkole nie wywodził się bezpośrednio z kręgów partii politycznych. Przez szereg lat po II wojnie światowej opozycja $\mathrm{w}$ stosunku do instrukcji religijnej w Szwecji była prawie nieznana. 
Program rządowy z roku 1950 na temat jedności szkolnictwa i program z 1962 dotyczący szkolnictwa podstawowego był akceptowany przez partie opozycyjne. Prawdziwa „bitwa” rozpoczęła się w roku 1964, kiedy zaprezentowano nowy program rządowy dla gimnazjum. W tym programie pojawił się nowy przedmiot - comparative religion studies, który zapoczątkował walkę. Mimo że wielu z członków parlamentu należących do partii opozycyjnych mówiło wielokrotnie o edukacyjnym znaczeniu religijnego wychowania, to jednak w tej atmosferze nie było jasne w praktyce wychowawczej i edukacyjnej szkoły, czy należy uczyć jedynie zasad etyki chrześcijańskiej (np. w ramach lekcji religii), czy też należy przekazywać chrześcijańską wiarę jako prawdziwą. W instrukcji z 1968 roku zaliczono lekcję religii do grupy innych przedmiotów nauczanych w szkole. Nie wszyscy zaakceptowali takie rozwiązanie i szukali możliwości utworzenia specjalnych chrześcijańskich szkół obok normalnego systemu edukacyjnego. Generalnie krytyka ze strony socjalistów w odniesieniu do szkoły i wychowania od końca lat sześćdziesiątych dotyczyła wielu przedmiotów szkolnych. Jednak w odniesieniu do religii i jej miejsca w szkole zarzuty były najbardziej ostre, gdyż dotyczyły elementów indoktrynacji o charakterze konserwatywnym, jakie rzekomo zawiera nauczanie religijne ${ }^{1}$. Oskarżenie to ewidentnie nie liczyło się z prawdą historyczną i prowadzoną przez wieki w ramach nauczania religii pracą edukacyjną Kościoła szwedzkiego. Ten wysiłek spowodował, że już przed wprowadzeniem obowiązku szkolnego w Szwecji w 1842 roku wielu Szwedów umiało czytać. Było to związane z faktem przynależności do Kościoła protestanckiego, gdzie umiejętność czytania rozwijana była ze względów katechetycznych. Do umiejętności pisania nie przykładano w tym czasie takiej samej wagi jak do umiejętności czytania ${ }^{2}$. Należy również podkreślić wobec tych, którzy także dziś przestrzegają przed niebezpieczeństwem religijnej indoktrynacji i nietolerancji ze strony szkół wyznaniowych fakt, że już przy końcu XIX wieku pojawiali się na$-517$.

${ }^{1}$ K. G. Agotsson, FrĆn katekestvĆng till religionsfrihet, Uppsala 1975, s. 515-

${ }^{2}$ E. Inger, Feläntk. En kritisk granskning av idebakgrunden till svens utbilningspolitik, Boktryckeri AB, Kristianstad 2001, s. 138-141. 
uczyciele negujący oficjalnie religijne wychowanie prowadzone w ramach szkolnego nauczania. Nie oznaczało to jednak ich zwalniania z pracy w szkołach (czy też represji), które miały konfesyjny charakter. Tak więc demokratyczne zasady, bez specjalnych deklaracji programowych w tym względzie, były stosowane już wtedy ${ }^{3}$.

\section{INTERKULTUROWOŚĆ, INTERNACJONALNOŚĆ \\ I TOLERANCJA W WYCHOWANIU I EDUKACJI W SZWECJI \\ JAKO ZABEZPIECZENIE POKOJU \\ I PORZĄDKU DEMOKRATYCZNEGO}

Termin „internacjonalizacja” został wprowadzony w szwedzkim systemie szkolnym i wychowawczym po I wojnie światowej i kojarzony jest w Szwecji z ruchem pokojowym. Po II wojnie światowej takie wartości, jak demokracja, sprawiedliwość i krytyczne myślenie znalazły się w centrum uwagi w odniesieniu do działań związanych z kształceniem i wychowaniem. Plany rządowe odnośnie do nauczania i wychowania ukierunkowywały się na wspieranie treści i programów interkulturowych w wychowaniu i nauczaniu. Szeroko rozumiana działalność edukacyjna wyraźnie stała się miejscem wychowywania obywateli wg pokojowych kryteriów internacjonalnych. Jeszcze silniej pojęcie internacjonalizacji zadomowiło się w Szwecji w drugiej połowie lat osiemdziesiątych XX wieku, ujawniając poprzez biznes i media swój aspekt ekonomiczny. Internacjonalizm wpłynął na podkreślenie w wychowaniu szkolnym znaczenia empatii we wzajemnych relacjach. Szkoła miała być środowiskiem ludzi o dobrych, otwartych postawach i powinna była sprzyjać empatycznemu rozwojowi osobowości uczniów, to zaś miało zabezpieczać przed rasizmem ${ }^{4}$. Zalecano, aby takie wychowanie prowadzić wobec wszystkich, gdyż w spotkaniu

${ }^{3}$ H. P. Hansen, VĆra barn Vägledning till uppfostran i hemmet, Tryck i Central + Tryckeriet, Stockholm 1900, s. 21.

4 U. Lundgren, Att forsoka tilsammans med studerande-nĆgra tankar, försök, slutsatser och förslag, w: H. A. Larsson, Den reflekterande medborgren, Jönköping University-AB SmĆland Quebecor 2000, s. 136-139. (135-159). 
międzykulturowym uczestniczą wszyscy. Odbywa się ono w różnoraki sposób i jest spotęgowane dzięki mediom przez prezentowane w nich wzory, przez dyskusje, które za ich pośrednictwem się toczą w odniesieniu do kulturowych różnic. To zróżnicowanie było i jest poważnym problem politycznym, społecznym i wychowawczym, gdyż mniejszości w Szwecji są liczne i mocno zróżnicowane kulturowo między sobą. Bardzo często są im obce tradycyjne wartości szanowane w Szwecji. Istnieje niebezpieczeństwo łatwego wykorzystania tych różnic dla celów politycznych. Generalnie różnorodność międzynarodowa i międzykulturowa może dawać szansę na wychowanie prowadzące do wzrostu zainteresowania ludzkimi odmiennościami. Stan ten może owocować większym zrozumieniem i empatią. W przeciwnym wypadku negatywna strona wielokulturowości stwarza niebezpieczeństwo separacji, dyskryminacji, kulturalnego rasizmu i narodowego szowini$\mathrm{zmu}^{5}$. Nikt nie może być poddany szykanom, zastraszaniu, ksenofobii, nietolerancji. Należy eliminować tendencje do molestowania. Szkoła powinna wychowywać do umiejętności życia w społeczności zróżnicowanej kulturowo ${ }^{6}$. Dlatego w programie inspirowanym internacjonalizmem nauczanie języka obcego jest jednym z najważniejszych zadań szkoły. Język angielski jest pierwszym językiem i ma on być pomocą w kontaktach międzykulturowych, dlatego jest przedmiotem obowiązkowym na przestrzeni lat szkolnych, a wiele dzieci uczy się go już w przedszkolu od czwartego roku życia. Także zglobalizowana kultura jest widziana jako pomoc w tym względzie. Telewizja i wszystkie media wspierają szkolenie w opanowaniu języka angielskiego. Wychodzi się z przesłanki, że cała edukacja i wychowanie powinny uczyć podejścia interkulturowego, dlatego angielski może być pomocny we wzajemnym zrozumieniu się?. Efekt spodziewany to nie tylko poznanie

5 J. Dacyl, Chellenges of cultural diversity in Europe, Centre for REasearch in International Migration and Ethnic Relations, Stockholm University 2001, s. 5-6, nr 4.

${ }^{6}$ Läroplan för det obligatoriska skolväsendet, förskoleklassen och fritidshemmet, Lpo 94, Ödeshög, DanagĆrds grafiska 2006, s. 3-4.

${ }_{7}$ U. Lundgren, Att forsoka tilsammans med studerande-nĆgra tankar, försök, slutsatser och förslag, w: H. A. Larsson, Den reflekterande medborgren, Jönköping University-AB SmĆland Quebecor 2000, s. 136-139. (135-159). 
kultury innej niż własna, ale także zrodzenie się pewnego dystansu do kultury własnej, zrozumienie jej słabych stron i podziw dla mocnych stron kultury innej ${ }^{8}$. Poznawaniu innych kultur niż kultura szwedzka służy wspomniane programowe nauczanie języka obcego, zwłaszcza angielskiego. W szwedzkim projekcie nauczania tegoż języka niektórzy autorzy dostrzegają nie tylko utylitarny cel ekonomiczny i użytkowy, lecz także szansę rozwijania głębszej i szerszej, nieograniczonej barierą językową, empatii międzyludzkiej i wychowania, któremu powinno sprzyjać poznawanie dobrych wartości zawartych w treściach lekcyjnych lekcji języka angielskiego, w tym duchu dobrych wartości. Niestety, jak to podkreślają niektórzy specjaliści, najczęściej nauka ta jest zogniskowana wokół koncepcji działania innej niż tej postulowanej koncepcji dobra. U. Lundgren twierdzi, że jeśli w obszarze nauczania języków obcych nie nastąpi przegrupowanie treści i motywów, to sam język i możliwość poznania innej kultury nie spowodują, że będą wzrastać jako realne takie wartości, jak pokój, demokracja, solidarność i równość ${ }^{9}$. Potrzebę przygotowania uczniów do relacji szerszych niż narodowe podkreśla jako zadanie dla szkół Szwedzka Narodowa Agencja Edukacji. Wskutek zmiennej sytuacji kulturowej zakłada się, że zawartość programów kształceniowych i wychowawczych co jakiś czas będzie wymagała ponownego rozpatrzenia. Zaznacza się, że oprócz wiedzy dotyczącej umiejętności językowych, matematycznych, wiedzy o świecie przyrodniczym i kulturowym, należy dążyć do poszerzenia wiedzy dotyczącej wspólnoty międzynarodowej. Jest to zadanie wychowawcze i edukacyjne bardziej aktualne niż w przeszłości. Kładąc nacisk na indywidualne predyspozycje ucznia, należy jednocześnie tak organizować zajęcia, aby rozwój własnych zainteresowań uczniów był ukierunkowywany na zajęcia szkolne i poszerzał społeczność uczniowską o innych spoza własnej grupy i klasy. Program mówi tutaj o wspieraniu wychowawczym rozwoju wolicjonalnego, samodzielności, wytrzymałości i dokładności wraz z rozwijaniem chęci współpracy z innymi. Zaznacza się też, że szkoła powinna przekazać wychowankom wartości zasad leżących u podstaw demokratycznego

\footnotetext{
8 Tamże, s. 143-144. (135-159).

9 Tamże, s. 156-157. (135-159).
} 
społeczeństwa. Uczeń powinien być świadomy znaczenia zwłaszcza takich pojęć, jak: uczciwość, szczerość, szacunek, tolerancja i konsekwencji łamania przepisów ${ }^{10}$.

Jeszcze mocniej niż w poprzednich programach zaznacza się potrzebę wychowania do życia w społeczeństwie umiędzynarodowionym w założeniach programowych z roku 2011. Zaleca się, aby z jednej strony kształtować zdolność rozumienia i współodczuwania z innymi ich wartości przy jednoczesnym dbaniu o rozwijanie świadomości własnego dziedzictwa kulturowego, gdyż tylko tak można zachować własną tożsamośćc ${ }^{11}$. Potrzeba wyjaśnienia wartości, norm i tradycji społecznych zwiększyła się w wielokulturowym społeczeństwie, co nie oznacza ich relatywizacji. Wielokulturowość wymaga od szkoły otwarcia się na nowe kultury, a także refleksji i przewartościowania dotychczasowych pozycji etycznych i dokonania wyborów, co często prowadzi do konfliktu. Zapobiec temu może promocja pluralistycznych wartości demokratycznych z naczelną zasadą równości wszystkich ludzi. Zwolennicy wychowania i edukacji otwartej na interkulturowość uważają, iż powszechne uznanie $\mathrm{w}$ relacjach międzyludzkich zasady równości jako podstawowej, rozwiąże problem konfliktów jakie mogą się rodzić wskutek różnorodności kulturowej. Uznanie tej wartości jako głównej ich zdaniem rozwiąże ten problem. Stawiając zasadę równości jako naczelną, jednocześnie negują możliwość przewagi jakiejś jednej tradycji etycznospołecznej w pluralistycznym społeczeństwie. Dlatego odrzucają jakąkolwiek tradycję chrześcijańską, islamską, marksistowską ${ }^{12}$. Występują także głosy krytyczne wobec tych idei, podkreślające, że nurt wielokulturowości atakuje zasadę wspólnej treści w programie nauczania danego kraju oraz zasadę, wg której wszyscy muszą spełniać pewne wspólne wymogi wychowawczo-edukacyjne ${ }^{13}$. Postulowana w wychowaniu idea wielokulturowości głosi, że każda kultura

10 Läroplan för grunskolan Lgr 69, Skolvöverstyrelsen 1969, s. 12-13.

11 Läroplan för grundskolan, fördkoleklassen och fritidshemmet 2011, Skolverket, Edita, VästerĆs 2011, s. 7-11.

12 G. Zackari, F. Modigh, Värde grunds boken - om samtal för demokrati $i$ skolan, AB DanagĆrds Grafiska, Stockholm 2000, s. 68-70, 72-73.

13 E. Inger, Feltänkt. En kritisk granskning av idebakgrunden till svensk ulbildningspolitik, Kristianstad Boktryckeri AB, Kristianstad 2001, s. 35-37. 
ma takie samo prawo do jej poszanowania. W praktyce oznacza to, że mniejszości, odwołując się do zasady tolerancji, żądają prawa szacunku ze strony większości, ale już niekoniecznie mniejszości szanują innych. Dawniej grupy mniejszościowe walczyły o to, aby były traktowane tak samo jak grupy dominujące, dziś chcą mieć prawo być innymi. Jest to stosunkowo nowe żądanie w odniesieniu do praw. Zasada ta zastosowana w edukacji i wychowaniu w Szwecji zaowocowała tym, że język szwedzki w nauczaniu szkolnym utracił rangę języka narodowego. Jest jednym z języków, jakie są nauczane w szkole. W Szwecji nauka języka szwedzkiego odbywa się dziś w mniejszym wymiarze godzin niż to było 20 lub 30 lat wcześniej ${ }^{14}$. Ponadto w szwedzkiej społeczności multikulturalnej wspiera się nauczanie języków rodzimych związanych z krajami pochodzenia imigrantów. Jednak nie idzie $\mathrm{z}$ tym $\mathrm{w}$ parze wystarczająca pomoc wychowawcza $\mathrm{w}$ opanowaniu przez imigrantów języka szwedzkiego. Dotyczy to zarówno pierwszego pokolenia przybyłego do Szwecji, a często także dzieci urodzonych już w Szwecji, których umiejętności językowe pozostają na niskim poziomie. Decyzje polityczne, wg których wielokulturowość jest wartością sprawiają, że podejmuje się duży wysiłek zapewnienia każdemu dziecku z rodzin imigranckich naukę języka kraju, z którego pochodzi. Wychodzi się tutaj z błędnych założeń, że język to jedynie sprawa opisu świata i przekazu informacji, zapoznaje się fakt, że język jest odbiciem całego życia człowieka. Dlatego dzieciom z rodzin imigrantów należy się pomoc w podtrzymaniu znajomości języka kraju, z którego przybywają, jednak należy także pamiętać, że całe codzienne odbicie ich życia obecnie, to życie w kontekście szwedzkim i nie jest obojętne dla nich i dla dobra Szwecji, w jakim stopniu zdołają opanować język kraju w którym żyją ${ }^{15}$.

Krytycy podkreślają niemożność zastosowania zasady wielokulturowości i tolerancji do całej polityki państwa, gdyż na gruncie społecznym i wychowawczym nie da się dostosować do kilku różnych kultur społecznych jednocześnie. Tymczasem tendencja zmniejszania literatury, historii, geografii, sztuki i muzyki widoczna w edukacji i wycho-

\footnotetext{
14 Tamże, s. 33-36, 112-115.

15 Tamże, s. 123-126.
} 
waniu w Szwecji od lat siedemdziesiątych XX wieku, może utwierdzać zwłaszcza młodych Szwedów i imigrantów w przekonaniu, że szwedzka tradycja kulturowa nie ma znaczenia ${ }^{16}$.

\section{DEMOKRATYCZNE WARTOŚCI \\ PODSTAWĄ BEZPIECZEŃSTWA WYCHOWAWCZYCH I EDUKACYJNYCH DZIAEAŃ SZKOLY}

Sven G. Hartman uważa, że wartością bazową w odniesieniu do wychowania i edukacji w szkołach publicznych w Szwecji jest demokracja ${ }^{17}$. Szwedzki system wychowawczo-szkolny oparty jest na wartościach tzw. värdegrund. Nie są to wartości jednoznacznie identyfikujące się $\mathrm{z}$ jakimś jednym systemem etycznomoralnym lub religijnym. System tych wartości jest określany przez Narodową Agencję Edukacji (Skoleverket) i przenika całość życia szkoły wpływając na nie poprzez ściśle określony sposób oddziaływania charakteryzowany przez następujące trzy podstawowe zalecenia i wartości:

1) Uczniowie mają zdobyć podstawową wiedzę na temat demokracji i jej fundamentalnych wartości. To dążenie powinno obejmować i wykorzystywać jak najszerzej całe tradycyjne nauczanie.

2) Sama szkoła powinna działać demokratycznie we współpracy z uczniami; wszyscy pracujący w szkole powinni wzmacniać życie szkoły, aktywnie na nie wpływając zarówno formalnie, poprzez organizacje szkolne, jak i nieformalnie, dając uczniom możliwość dyskusji i wpływu na zawartość oraz przebieg lekcji.

3) Szkoła jest odpowiedzialna za edukację i wychowanie demokratycznych członków wspólnoty. To nakłada obowiązek wychowania uczniów w duchu trzech podstawowych wartości demokratycznych: solidarności, równości ludzkich istot i takich samych możliwości ${ }^{18}$.

16 Tamże, s. 33-36.

17 S.G. Hartman, R. Furenhed, Etik och ungas livstolkning, Linköpings Universitet, LTAB, Linköping 2003, s. 9-11.

18 Por. Skoleverket, Demokratie och värdegrund, 2005. 
Program nauczania z 1980 roku podkreśla, że wychowanie prowadzone przez szkołę powinno być pomocne dla wychowania domowego (hemmet i en fostran), którego celem jest przekazanie dzieciom demokratycznych wartości społeczeństwa. Również w tym przypadku nie używa się klasycznego określenia „wychowanie rodzinne”, lecz „wychowanie domowe", które w kontekście wychowania i edukacji jest nieprecyzyjne. Ponadto wychowanie rodzinne, a więc zgodne z wolą ojca i matki jest tu podporządkowane wartościom demokracji. W programie podkreśla się, że obowiązkiem rodziców jest nadzorowanie obecności dziecka w szkole. Wszelkie nieobecności powinny być sygnalizowane wcześniej o ile to możliwe. Zadaniem szkoły jest utrzymanie stałych kontaktów z rodzicami. Obowiązkowe jest spotkanie przynajmniej dwa razy do roku i indywidualna rozmowa $\mathrm{z}$ nauczycielem na temat wychowania i kształcenia dziecka. Zaleca się, aby w tej rozmowie mogło uczestniczyć także dziecko, z powodu którego takie spotkanie się odbywa. Tak jak i w poprzednich programach potwierdza się zadanie szkoły zorientowania się w sytuacji domowej dziec$\mathrm{ka}^{19}$. Wydaje się, że odniesienie do wartości demokratycznych jeszcze mocniej niż w poprzednich programach podkreśla program nauczania z 1994 roku. Już na samym wstępie stwierdzono, że system szkół publicznych opiera się na zasadach demokratycznych. Zadaniem szkoły jest promocja i wpajanie szacunku do wartości, gdyż na nich jest oparte życie społeczeństwa szwedzkiego. Zalicza się do nich przede wszystkim: nienaruszalność ludzkiego życia, indywidualną wolność osobistą i integralność, równość i solidarność między mężczyznami i kobietami. Dużą wagę należy też przykładać do wspierania u jednostek poczucia sprawiedliwości, hojności, tolerancji i odpowiedzialności. Podkreśla się, że jest to zgodne z tradycją etyki chrześcijańskiej i zachodniego humanizmu ${ }^{20}$. Deklaracja ta, jak i wytyczne z nowszych programów nauczania nie powodują, że szkoła może funkcjonować jako szkoła wyznaniowa. Odwrotnie: w imię wartości demokratycz-

19 Läroplan för grunskolan, Allmändel, MĆl och riktlinjer, timplaner, kurplaner, Skolvöverstyrelsen 1980, s. 24-25.

${ }^{20}$ Läroplan för det obligatoriska skolväsendet, förskoleklassen och fritidshemmet, Lpo 94, Ödeshög, DanagĆrds grafiska 2006, s. 3-4. 
nych i poszanowania godności człowieka, bezwyznaniowość szkoły jest potwierdzona także $\mathrm{w}$ najnowszych założeniach programowych i wychowawczych z roku 2011. W ten sposób zakłada się, że szkoła będzie aktywnie przeciwdziałać nietolerancji i ksenofobii. Zaznacza się w tym programie, że nie tylko ma być przekazywana wiedza o wartościach demokratycznych, lecz wszelkie nauczanie szkolne powinno być także prowadzone $\mathrm{w}$ formach demokratycznych. Pozwoli to na najlepsze przygotowanie uczniów do aktywnego uczestnictwa w życiu społecznym. Dla zrealizowania tego celu zaleca się, aby uczniowie uczestniczyli w planowaniu codziennej nauki. W ten sposób nauczą się wpływania na decyzje i podejmowanie odpowiedzialności ${ }^{21}$. Jednoznacznie stwierdza się, że szkoły powinny aktywnie i świadomie wpływać i pobudzać uczniów do przyjęcia wspólnych wartości społeczeństwa. Jednocześnie stwierdza się, że każdy uczeń może tworzyć i wyrażać stanowiska etyczne pod warunkiem, że są one oparte na prawach człowieka i podstawowych wartościach demokratycznych. Także zdobywana wiedza i nabyte umiejętności są podstawą do pełnego włączenia się do społeczności jako aktywny jego członek. Zaznacza się, że odpowiedni poziom zdobytej wiedzy warunkuje dalsze kształcenie. Wylicza się w programie obszary wiedzy, za których przekazanie odpowiedzialna jest szkoła ${ }^{22}$. Ścisłe przestrzeganie przez szkoły i praktykowanie zasad demokratycznych w praktyce edukacyjno-wychowawczej powinno dać pewność rodzicom, że dzieci ich nie będą przeciągane na jakąś jedną stronę odnoszącą się do filozofii walki cywilnej, przejawiającej się w różnicy zdań i przekonań, że nie dostaną się pod wpływ jakiegoś jednego dominującego światopoglądu. Rodzice muszą mieć pewność, że szkoła i nauczanie, jakie dzieci otrzymują, spełniają kryterium obiektywności, wszechstronności i standardów demokratycznych wartości. Jednocześnie zarówno rodzice, jak i dzieci muszą w praktyce kierować się szacunkiem dla wszystkich ludzi i ich wartości, które oficjalnie są uznane przez państwo szwedzkie. Podkreśla się, że szkoła nie może zajmować stanowiska neutralnego wobec

21 Läroplan för grundskolan, fördkoleklassen och fritidshemmet 2011, Skolverket, Edita, VästerĆs 2011, s. 7-11.

22 Tamże, s. 12-14. 
podstawowych demokratycznych wartości, lecz powinna się zdecydowanie odcinać od wszystkiego, co stoi w sprzeczności z nimi ${ }^{23}$.

Demokratycznych wartości nie da się osiągnąć przez zwiększenie kontroli w szkołach, lecz należy dążyć do zintegrowania wartości z innymi działaniami. Wychowanie, które chce promować wartości demokratyczne, musi być regularne, powinno być prowadzone w ramach każdego przedmiotu ze świadomością, że nauki społeczne, historia, filozofia i religia dają szczególne ku temu możliwości. Wychowawcy, nauczyciele powinni zachować świadomość, że niejako sprawdzianem tego wychowania są reakcje uczniów w konkretnych sytuacjach życiowych, np. wobec prób zastraszania w szkole ${ }^{24}$. Demokratyczne wartości i prawa człowieka będą podtrzymane, jeśli szkoła wypełni swoją socjalizacyjną, tj. wychowawczą funkcję, tzn. jeśli etyczne i egzystencjalne problemy będę podtrzymane i znajdą swój wyraz we wszystkich aspektach szkolnej pracy, organizacji, w edukacyjnych metodach i we wszystkich dominujących postawach. Każda szkoła ma wolność w sposobie interpretacji realizacji celów przedmiotowych zawartych $\mathrm{w}$ programie z zastrzeżeniem, iż bazowe wartości zapisane w programie narodowym mają znaleźć swoje praktyczne zastosowanie. Widać tu wyraźnie konkretny zamiar wychowawczy organu nadrzędnego, tj. centralnych instytucji państwowych. Ta świadomość wychowawcza lub formacyjna widoczna jest także w samym sposobie określania wiedzy, która nie jest tylko zestawem ustalonych elementów przekazywanym odbiorcy. W programie jest przytoczona definicja $\mathrm{z}$ oficjalnego rządowego raportu, wg której wiedza nie jest zewnętrznym akcesorium osoby, lecz staje się częścią osobowości. Konsekwentnie uznaje się, że wiedza zdobywana nie jest suchym studiowaniem faktów i koncepcji, lecz jest także poznawaniem pewnego porządku rozumienia rzeczy i używania koncepcji w różny sposób. Dlatego tak ważne jest,

23 Läroplan för grunskolan Lgr 69, Skolvöverstyrelsen 1969, s. 10, 14; Läroplan för grunskolan, Allmändel, MĆl och riktlinjer, timplaner, kurplaner, Skolvöverstyrelsen 1980, s. 18-19; Läroplan för det obligatoriska skolväsendet, förskoleklassen och fritidshemmet, Lpo 94, Ödeshög, DanagĆrds grafiska 2006, s. 4.

24 G. Zackari, F. Modigh, Värde grunds boken - om samtal för demokrati i skolan, AB DanagĆrds Grafiska, Stockholm 2000, s. 87-89. 
czego uczniowie uczą się w szkołach i jak się uczą. Jednym z głównych zadań szkoły, myśląc w tym duchu, jest przekazanie kulturalnego bogactwa i tradycji, języka i wiedzy następującym po sobie generacjom, jak i przygotowanie młodzieży do życia i pracy w przyszłości. Naturalnym miejscem zdobywania wiedzy jest dom rodzinny i szkoła. W dobie rozwoju nowych technologii zdobywanie wiedzy przeniosło się w dużym stopniu do domu, lecz niestety w tym samym czasie szkoła i rodzice stracili kontrolę nad tym, czego dzieci się uczą, dzieci zaś zostawiły swoich bliskich. Zadaniem szkoły jest więc nauczyć rozróżniania, analizowania oraz integrowania wiedzy poprzez wartości, jakich szkoła ma strzec, a także umożliwienie posługiwania się nowoczesnymi narzędziami komunikacji i zdobywania wiedzy także tym, którzy z różnych przyczyn potrzebnych narzędzi nie posiadają ${ }^{25}$.

Nieprzypadkowo cały system szkolny jest ukierunkowany na współpracę szkoły i lokalnej społeczności. Zakłada się, iż przyniesie to zamierzony skutek wtedy, gdy przede wszystkim w szkole wszyscy z sobą będą współpracować. Takie nastawienie wychowawcze ma wpływ na treść dnia szkolnego i stymuluje rozwój uczniów jako aktywnych członków korporacji, tj. ludzi, dążących do realizowania wartości demokratycznych i pracujących dla poprawy społeczeństwa. Zamiarem wychowawczym jest przede wszystkim przeciwdziałanie pasywności i uświadomienie młodzieży, że każdy młody człowiek jest składnikiem aktywów grupy i uruchamiając swoje własne aktywa niejako kapitalizuje je i może doświadczyć, że są one ważne i wartościowe dla innych w szkole. Z faktu, że w ten sposób młody człowiek może wpływać na otoczenie winien czerpać swoją pewność i zadowolenie ${ }^{26}$.

25 The Swedisch National Agency for Education, A Schoool for the future - the ideas underlyning the reform of upper-secondary education in Sweden, Stockholm 1997, s. 12-13.

${ }^{26}$ Förslag till förändring av grundskolans läroplan, Till Regeringen Utbildningsdepartament, nr 2.2; 3.1. 


\section{NiEBEZPIECZEŃSTWA ZWIĄZANE}

\section{Z ZAPOZNANIEM NAUCZANIA HISTORII}

Niektórzy autorzy podkreślają konieczność budowania przez wychowanie i edukację prawidłowej świadomości historycznej w celu ochrony i bezpieczeństwa demokratycznych wartości i demokratycznego porządku. Znajomość historii pozwala z większym szacunkiem patrzeć na teraźniejszość. Prawidłowo ukształtowana świadomość historyczna jednostki i społeczeństwa sprzyja krytycznemu myśleniu, które pozwala uniknąć wielu błędów. Wychowanie szkolne powinno zmierzać do tego, aby uczniowie zdobyli fundamentalną świadomość historyczną i umiejętność postrzegania historii, która ułatwia zrozumienie teraźniejszości i przygotowuje do przyszłości. Taka perspektywa wychowawcza i edukacyjna w odniesieniu do historii jest procesem długotrwałym. Jest to podstawowy problem, z którym borykają się nauczyciele historii we współczesnej szkole w Szwecji, dlatego większość uczniów szkół podstawowych i gimnazjum kończy naukę z niedostateczną znajomością historii ${ }^{27}$. Prowadzona przez wieki działalność kształceniowa, szkolna i wychowawcza w Szwecji dostarcza wielu informacji na temat roli nauczania historii dla właściwego wychowania człowieka. Plan nauczania dla szkół podstawowych obowiązujący w latach 1900 do 1919 zmniejszał o połowę liczbę godzin przeznaczonych na nauczanie Pisma Świętego, odpowiednio zwiększając w to miejsce liczbę godzin przedmiotów (także historii i geografii) orientujących odpowiednio postawę obywatelską. Jeśli chodzi o ostatnie 40 lat XX wieku, to pomimo świadomości ważności historii w procesie wychowania liczba godzin tego przedmiotu w szkołach podstawowych zmniejszyła się radykalnie, najbardziej wyraźny spadek nastąpił w latach dziewięćdziesiątych XX wieku. Interesujący jest fakt, że o ile zmiany przeprowadzone w latach dwudziestych były spowodowane troską o należyte zorientowanie społeczeństwa w nowo-

27 M. Lindman Johansson, Historieämnet $i$ skolan. En analys av debatten sedan 1940, w: H. A. Larsson, Den reflekterande medborgren, Jönköping University-AB SmĆland Quebecor 2000, s. 49 (49-64). 
czesnym świecie (tym uzasadniano zmiany programowe zwiększające ilość godzin lekcji historii), o tyle odnośnie do zmian dokonywanych na przestrzeni lat 1940-1994 nie wykazano żadnych motywów tych działań. Oficjalnie ciągle uważano historię za ważną lekcję, jednak liczba godzin tego przedmiotu zmniejszyła się w tych latach w stosunku do innych. W niektórych wypowiedziach ze strony rządowej można się dopatrzyć możliwych przyczyn takiego postępowania. Mianowicie uczyniono tak, gdyż uważano, że uczniowie otrzymali już wcześniej wyczerpujące i cenne orientacje historyczne za pośrednictwem radia, telewizji, prasy i filmu ${ }^{28}$. Wielu autorów zajmujących się sprawami wychowania jest zaskoczonych i rozczarowanych tym, że z jednej strony politycy zgadzają się, iż wiedza historyczna jest ważna i może zmniejszać wrogość między ludźmi, lecz jednocześnie w działalności praktycznej nie idą za tym przekonaniem, postępują odwrotnie, zmniejszając liczbę godzin historii w szkole. M. Lindman Johansson zauważa, iż jest to paradoksalne, że zainteresowanie historią ze strony ludzi wzrasta, a rząd zmniejsza liczbę godzin lekcyjnych przeznaczonych na jej solidne studiowanie. Sytuacja powyższa powoduje, że każdego roku opuszcza szwedzkie szkoły około 10 tys. ludzi, którzy nic nie wiedzą o swojej i o innych kulturach. Taki stan wiedzy historycznej domaga się wprowadzenia większej liczby godzin historii na wszystkich poziomach nauczania. W szkole podstawowej historia przestała istnieć jako samodzielny przedmiot nauczania. Faktem najbardziej negatywnym w tym względzie jest to, że aż w 13 z 16 programów narodowych w szkołach średnich nie znajduje się historia jako przedmiot obowiązkowy. Oznacza to, że bardzo duża liczba młodzieży nie otrzymuje wychowania bazującego na zapoznaniu się z bohaterami narodowymi i nie jest wprowadzana w świat wartości przez nich reprezentowany. Badania przedstawiają brak krytycznej postawy u tych osób w odniesieniu do propagandy ze strony różnych niedemokratycznych ruchów i odwrotnie: ta krytyczna postawa jest wyraźnie większa u tych, którzy w programie szkolnym wybrali kurs teoretyczny historii. Jeśli ta

28 Tamże, s. 50-53. (49-64). 
niekorzystna sytuacja wychowawcza nie ulegnie zmianie, przyszłość demokratycznego społeczeństwa może być zagrożona ${ }^{29}$.

\section{Problem etyki W Wychowaniu i W edukacji}

Coraz częściej w dyskusji na temat bezpiecznych programów oraz struktur edukacyjnych i wychowawczych w Szwecji podkreśla się rolę fundamentów etycznych. Szukając np. rozróżnienia między etyką i moralnością, zauważa się, że w szwedzkiej literaturze nie ma na ten temat wielu opracowań. Zakari i Modih stwierdzają, że etyka skupia się na refleksji w odniesieniu do wartości człowieka oraz w stosunku do tego, co określamy jako dobro i zło. Natomiast moralność jest wartością, która przejawia się w działaniu i wiąże się z normami ${ }^{30}$. Zaznaczają, że o tym, jakie normy są stosowane decydują społeczne tradycje. Wybór i interpretacja tych wartości zależny jest od ideologii i światopoglądu, jakim kierują się ludzie w danej społeczności. W odniesieniu do fundamentalnych opcji światopoglądowych i kulturowych deklaruje się, że szwedzkie programy nauczania oparte są na idei zachodniego humanizmu i etyce chrześcijańskiej. W odniesieniu do tego zapisu umieszczonego w oficjalnym programie nauczania prowadzone są ciągłe dyskusje, w których dosyć często występują głosy sprzeciwu w odniesieniu do etyki chrześcijańskiej. Z tego kręgu wywodzą się propozycje zmiany w programie określenia „etyka chrześcijańska” na „etyka człowieka”. Pomysły te są często krytykowane przez społeczeństwo Szwecji. Należy stwierdzić, że u podłoża nieakceptacji etyki chrześcijańskiej jako wskazania zawartego w szkolnym programie wychowania i nauczania leży idea neutralności światopoglądowej i etycznej państwa, a także niekonfesyjny charakter szkoły. Wielu autorów nie zgadza się z zasadami, na podstawie których odrzuca się w wychowaniu szkolnym etykę chrześcijańską. Janina Dacyl uważa, że idea etycznej neutralności szkoły i szkolnego wychowania jest tu niewystarczająca. Podkreśla ona, iż za-

29 Tamże, s. 54-55; 57; 59; 63-64. (49-64).

30 G. Zackari, F. Modigh, Värde grunds boken - om samtal för demokrati i skolan, AB DanagĆrds Grafiska, Stockholm 2000, s. 19-20, s. 36. 
równo nauczyciel, jak i wszystkie działania szkoły nie mogą charakteryzować się neutralnością w stosunku do etyki, moralności i światopoglądu. Sytuację wychowawczą, w której nauczyciel nie ujawnia swego stanowiska etyczno-moralnego nazywa naganną. Podstawowe wartości etyczne muszą być jasno określone i nie mogą być zmienione przez demokratyczną decyzję większości, gdyż etyka i jej zasady nie opierają się na decyzjach uprawnionych do głosowania. G. Zackari, F. Modigh podają tutaj przykład, że np. demokratycznie głosując nie można przywrócić kary cielesnej w szkole, zakaz etyczny nie podlega decyzjom ludzi, lecz decyzje ludzkie muszą się do niego dostosować. Rozmowy, jakie należy prowadzić w szkole na temat różnych stanowisk moralnych, nie oznaczają zawieszenia zasad etycznych, na których oparta jest idea demokracji ${ }^{31}$. Termin „etyczna nauka”, która mogłaby znaleźć zastosowanie na tym gruncie jest terminem stosunkowo nowym i także nie przez wszystkich przyjmowanym, lecz postrzeganym jako problematyczny $^{32}$. Celem zasad etycznych jest przede wszystkim ochrona uczniów i ich prawo do wysokiej jakości edukacji. W stosunku do pozycji uczniów w szkole nauczyciele mają przewagę. Poprzez rozwój etycznego podejścia można zmniejszyć ryzyko, jakie ta sytuacja może stwarzać. Przyczyni się to także do wzrostu zaufania do nauczycieli ${ }^{33}$. Samo ogólne zalecenie działania w najlepszym interesie ucznia kierowane do nauczycieli i wychowawców w wielu przypadkach nie wystarcza, gdyż jest zbyt ogólnikowe. Nauczyciel w Szwecji niejednokrotnie jest narażony na konflikt w momencie, gdy jego uczniowie i ich rodzice stoją na pozycjach etycznych i światopoglądowych sprzecznych z liberalną i demokratyczną wizją szwedzkiego społeczeństwa. Często dzieje się tak w przypadku uczniów, których rodzice są imigrantami. W takich warunkach decyzja nauczyciela na temat tego, co jest istotnym dobrem ucznia jest bardzo trudna. Sytuację komplikuje wymaganie, aby nauczyciel, podejmując konkretne działania wychowawcze, zachował świadomość, że wartości i normy stosowane w szkołach w procesie wy-

31 Tamże, s. 19-20 (38-42).

32 Tamże, s. 94-97.

33 Lärarförbundet, Yrkesetik i vardagen - fördjupningsmaterial, Modintryckoffset 2006, s. 5. 
chowawczym powinny być osadzone w kontekście określonej etyki jako systemu, a także w realiach etyki środowiskowej ${ }^{34}$. Ponadto oczekuje się jako rzeczy oczywistej, że szkoła zapewni biegłość dzieciom i młodzieży we wszystkich przedmiotach, co pomoże uczniom być bardziej kompetentnymi w wielu dziedzinach. Szkoła powinna także przekazać młodzieży dobre wychowanie, odpowiednie wzorce etyczno-moralne utwierdzające $\mathrm{w}$ nich szacunek do wartości ludzkich. Chociaż uczniowie wykazywaliby się dobrą orientacją $\mathrm{w}$ wiedzy przedmiotowej, to jednak bez przejęcia odpowiednich wzorców byłaby to porażka wychowania i szkoły. Autorzy słusznie zauważają, że komory gazowe w obozach zagłady były zbudowane przez uczonych inżynierów, a dzieci i niemowlęta zabijane przez wykształconych lekarzy i pielęgniarki. Wszystkie zajęcia szkolne muszą być oparte na utwierdzaniu podstawowej postawy etycznomoralnej, dostrzegania osoby w każdym człowie$\mathrm{ku}^{35}$. W wychowaniu należy dążyć też do tego, aby jednostka była świadoma znaczenia pojęć etycznych, takich jak: sprawiedliwość, uczciwość, szacunek, tolerancja i konsekwencji, jakie powoduje łamanie przepisów ${ }^{36}$. Inger Enkvist, odwołując się do myśli angielskiego filozofa Russella, zauważa, że brak szczęścia związany jest z nierealistyczną wizją życia, etyki i złymi nawykami osobistymi. Szczęśliwi ludzie, jej zdaniem, nie myślą o sobie, lecz o dobru innych. Ponadto rozwijają działalność, która nie zależy od ich sytuacji osobistej, a która pomaga im osiągnąć równowagę psychiczną. Umieją przyjąć odpowiedzialność za swoje czyny, gdyż brak tej odpowiedzialności prowadzi do nieszczęścia. Sukces można osiągnąć tylko długoterminową pracą, dlatego dziecko winno być wychowywane do pracy tak, aby mogło pogodzić się monotonią życia. Człowiek buduje swoją osobowość moralną, ucząc się dobrych nawyków związanych z pracą. Generalnie dobre nawyki są podstawą dobrego wychowania i szczęścia dziecka w przyszłości ${ }^{37}$.

34 R. Fjellström, Läraryrkets sammanstta etik, Lärarnas Riksförbund, www. Ir.se 2012, s. 1-2, 9-8.

35 G. Zackari, F. Modigh, Värde grunds boken - om samtal för demokrati i skolan, AB DanagĆrds Grafiska, Stockholm 2000, s. 6-9.

${ }^{36}$ Läroplan för grunskolan, Skolvöverstyrelsen 1962, s. 15.

37 I. Enkvist, Uppfostran och utbildning, WS Bookwell, Finland 2007, s. 28-33. 
Znaczące są tutaj na gruncie szwedzkim uwagi, jakie w tym kontekście daje S. G. Hartman, który też wskazuje polskiego pedagoga Janusza Korczaka i jego nauczanie jako przykład wychowania i pedagogiki opartej na dobrze umontowanym fundamencie etycznym. Hartman, podkreślając znaczenie moralności w wychowaniu, dostrzega problem z formowaniem wrażliwości i pryncypiów moralności, które mogą być zależne od wielu czynników. Zauważa, że chociaż moralność nie jest prostą konsekwencją umiejętności filozoficznych i swoim zasięgiem dotyka tajemnicy duszy ludzkiej, to jednak w wychowaniu i kształceniu widzi wyraźną potrzebę ćwiczeń formacji etycznej, która opierając się na teoriach etycznych może dać uczniom spójne rozumowanie i pomoże im uświadomić sobie własną wartość i godność. Tym samym wytworzona zostanie platforma do działania moralnego. Nie można wobec moralności pozostawać na płaszczyźnie irracjonalnej, gdyż historia i współczesność dostarczają wielu tragicznych dowodów na to, jak zgubne są dla całych społeczności skutki takiej postawy ${ }^{38}$. Tymczasem G. Zackari i F. Modigh uważają, że program nie dostarcza takich jednoznacznych wskazówek, koncentruje się na ogólnych wskazaniach etycznych ujmowanych abstrakcyjnie, nie formułuje jednoznacznych czytelnych standardów ${ }^{39}$. Wskazując na braki w wychowaniu etycznym i moralnym, Hartman zauważa, że edukacja może być także przeszkodą w wychowaniu do przestrzegania dobrych obyczajów ${ }^{40}$. Hartman w swojej ocenie, odnosząc się do wychowania i funkcjonowania szkoły w Szwecji, stawia także na pierwszym planie potrzebę jasnych kryteriów etycznych. Jego zdaniem etyka jest głównym problemem. Zaznacza jednak, że sama koncepcja potrzeby etyki nie mówi nic o tym, jak sprawa ta powinna być zdefiniowana i zakotwiczona. Generalnie wszystkie poglądy, także niedemokratyczne, mają tendencję trzymania się jakichś własnych koncepcji etycznych. Odwołując się do oficjalnych

38 S. G. Hartman, R. Furenhed, Etik och ungas livstolkning, Linköpings Universitet, LTAB, Linköping 2003, s. 48-49.

39 G. Zackari, Fredrik Modigh, Värde grunds boken - om samtal för demokrati i skolan, AB DanagĆrds Grafiska, Stockholm 2000, s. 78-85.

40 S. G. Hartman, R. Furenhed, Etik och ungas livstolkning, Linköpings Universitet, LTAB, Linköping 2003 s. 50-51. 
planów edukacyjnych, ustala podstawowe wartości, na których opierają się szkoły publiczne w Szwecji. Jako wartość bazową wskazuje zasady demokracji, dla której każdy pracujący w szkole powinien się trudzić. Następnie wymienia szereg ogólnych wartości normatywnych: zrozumienie i współczucie, obiektywizm i kompleksowość, równoważne wykształcenie, prawa i obowiązki. Jego zdaniem one stanowią grunt etyczny dla podstawowych wartości wychowawczych i edukacyjnych. Struktura programu nauczania wartości obejmuje trzy elementy składowe: 1) demokracja; 2) liczbę wartości (zasadniczo chodzi o wartości wymienione wyżej); 3) określa cztery cnoty i ideały wychowawcze, tj. poczucie sprawiedliwości, wspaniałomyślność, tolerancja i odpowiedzialność ${ }^{41}$. Autor wydaje się podzielać opinię, że wychowanie i edukacja szkolna są warunkami budowania demokratycznej społeczności. Jednocześnie zaznacza, że także niedemokratyczne społeczności wykorzystywały wychowanie, edukację i szkołę dla swoich celów. Asymetryczna struktura szkoły może wzmacniać niedemokratyczne tendencje. Zagrażają one zarówno nauczycielom, jak i uczniom. W tym kontekście podkreśla, że w Szwecji istnieje napięcie między nauczycielami a rodzicami uczniów. Nauczyciele wydają się przejmować część terytorium rodziców, objawia się to konfliktem praw. Ma to swoje podłoże historyczne, gdyż stary szwedzki system wychowania w domu rodzinnym koncentrował się na nauczaniu obowiązków. Od momentu wprowadzenia obowiązkowego nauczania zadanie to przeszło na nauczycieli, którzy zagarnęli niejako dotychczasową rolę domu rodzinnego. Stąd w wychowaniu i edukacji szkolnej w Szwecji występuje tyle napięć, których reperkusje mają swoje odbicie w międzynarodowym wymiarze sprawiedliwości. Do takich spornych kwestii należy np. obowiązkowa edukacja seksualna i religijna. Już sam ten kontekst pokazuje, że szwedzki system szkolno-wychowawczy zwłaszcza w kwestii spraw takich, jak relacja między misją szkoły społecznej i misją rodzicielską powinny podlegać stałej profesjonalnej refleksji etycznej. Refleksja ta wzmocni prawo rodziców do wpływania na szkołę. Jest to konieczne, gdyż zdaniem autora szwedzka szkoła i wychowanie nie są neutralne. Szkoła jest odpowiedzialna za edukację ideologiczną dzieci.

41 Tamże, s. 9-11. 
Jej skutkiem jest utajony konflikt etyczny. Nauczyciele mogą sobie $\mathrm{z}$ nim poradzić jedynie $\mathrm{w}$ takim przypadku, kiedy świadomie potrafią się odwołać do wartości i prawd uzasadnionych od strony etycznej. Ważne jest to ze względu na postulowane dobro indywidualne dziecka i całej społeczności i dlatego np. dokonywanie utajonej konwersji przez wychowanie szkolne nie jest celem szkoły ${ }^{42}$. Hartman zauważa, że w Szwecji brakuje świadomie sformułowanej etyki nauczycielskiej w języku szwedzkim. Nauczycielskie związki zawodowe w ostatnich latach rozpoczęły pracę nad sformułowaniem kodeksu etyki zawodowej. Jednak zanim świadomość etyczna przeniknie do powszechnej świadomości nauczycieli, minie jeszcze sporo czasu. Ten brak podbudowy etycznej zawodu i etosu nauczyciela Hartman wiąże z historyczną perspektywą szwedzkiej edukacji i pracy wychowawczej prowadzonej jego zdaniem na podstawie angelicznej luterańskiej wizji, którą realizowano szczególnie w murach szkoły. W tej optyce nie było potrzeby tworzenia rozważań o charakterze etycznym, gdyż to co jest słuszne, a co złe wydawało się tak oczywiste, że teoretyczne rozważania były zbędne. Nie potrzebna też była formacja świadomości nauczycieli w tym względzie. To, co studiował nauczyciel, przygotowując się do zawodu, a co można nazwać pedagogiką ewangelicką, było wystarczające do funkcjonowania tego systemu wychowawczo-edukacyjnego. Współczesna szkoła działa i wychowuje w atmosferze pluralistycznej kultury. Znikła jedna słuszna i unikalna wizja życia i spraw człowieka. Główne reformy edukacyjne i wychowawcze w XIX wieku były osadzone w nurcie progresywizmu edukacyjnego, który nie poświęcał wiele uwagi zagadnieniom etycznym. Szkoła miała zapewnić wychowanie i kształcenie oparte na osiągnięciach nauki zakotwiczonej w doświadczeniu. Nastawienie wychowania i szkolnej edukacji było ściśle pragmatyczne. W rozwiązaniach, które stosowano, nie podejmowano żadnej etycznej analizy w odniesieniu do moralnej oceny pracy nauczycieli. Komitet zajmujący się oceną spraw nauczania w Szwecji skrytykował ten okres. Inni - wydaje się, że broniąc tej linii - podkreślali, że myślenie tego typu jest charakterystyczne dla inżynierii społecznej ostatecznie prowadzącej do zbudowania silniejszej społeczności. Hartman zaznacza, że tego typu

42 Tamże, s. 25-30. 
argumentacja jest charakterystyczna dla zwolenników nieograniczonej wiary w naukę i zagraża wolności oraz integralności obywateli. Wszystkie te zjawiska wskazują, że poziom refleksji etycznej w tym okresie był bardzo ograniczony. Od tego czasu wpływ na szkoły przejęły siły polityczne, które szkołę i wychowanie chcą opierać jedynie na naukowych - doświadczalnych zasadach i świadomie unikają problematyki etycznej. W połączeniu z nasilającą się sekularyzacją wytworzyło to pustkę, zwłaszcza w odniesieniu do zasad etycznych. Zdaniem Hartmana jest to kolejny powód, aby kwestie etyczne w kontekście edukacji, wychowania i zawodu nauczyciela uczynić bardziej aktualnymi. Zaznacza, że etyczne przygotowanie nauczycieli ograniczone jedynie do znajomości ustaw rządowych i planu nauczania jest najbardziej nieprofesjonalne z możliwych. Zdradza ono brak perspektyw teoretycznych. Ogólne dyrektywy programowe w odniesieniu do dziedziny etyki zwykle charakteryzują się niejasnością i zmuszają nauczycieli do poszukiwania konsensusu. Nie jest on spowodowany pluralizmem kulturowym, lecz właśnie owym brakiem przejrzystości. Kwestie etyczne są tak niejasne, że muszą być wspólnie interpretowane przez nauczycieli, a to nie może przynieść efektów w pluralistycznym społeczeństwie, gdyż otrzymali oni wykształcenie bez odniesienia i świadomości etyki zawodowej43. W wychowaniu, zwłaszcza szkolnym, w Szwecji widać wyraźnie negatywny wpływ postmodernizmu. Przykłada się dużą wagę do estetyki, pomijając wagę zagadnień etycznych. Ważne są kwestie związane z modą, muzyką, odzieżą, przy jednoczesnym braku motywacji do nauki. Wydaje się, że nie istnieje także jednolita koncepcja prawdy, dobra i piękna, dlatego też wszystkie kultury przedstawia się jako równoważne. Także współpraca w grupach nie ma większego wpływu na studentów, gdyż decydujące są komunikaty konsumpcji, np. tanie rozrywki. Uwaga, którą poświęca się współcześnie oglądaniu telewizji wskazuje, że społeczeństwo jako takie, już nie wzbudza naszego zainteresowania. Dlatego też w wychowaniu wydaje się anachronizmem domagać się pewnego porządku studiów. Wszystko ma być zabawne i poddane swobodnemu wyborowi. Swobodny wybór kursów studiów jest postmoder-

43 Tamże, s. 16-18. 
nistyczną ideą ${ }^{44}$. Zmiany programowe $\mathrm{w}$ zakresie wychowania i nauczania wprowadzone $\mathrm{w}$ latach pięćdziesiątych i sześćdziesiątych XX wieku spowodowały, że wychowanie zostało pozbawione jednoznacznych odniesień etycznych, stało się jedynie pomocą, jakiej może udzielić jednostce grupa w drodze do stawania się lepszym, jednak bez wyraźnie określonych odniesień etycznych. Nie zakładano też w wychowaniu określonego systemu etycznego, poza ogólnym trendem wspierania wartości demokratycznych ${ }^{45}$. Jest to zgodne z pragnieniami tych, którzy powołując się na zasady tolerancji, neutralności światopoglądowej i niekonfesyjności szkoły (generalnie w wychowaniu, a najbardziej w wychowaniu szkolnym), nie akceptują żadnej tradycji w ustaleniu zasad etycznych, gdyż ich zdaniem każde dziedzictwo kulturowe wiąże ludzi, ale też wyklucza i ogranicza tych, którzy nie są częścią tego dziedzictwa. Szkoła nie może być wyznaniowa i nie może popierać żadnej religii. Nie może jednak zamknąć się na zjawisko religijne, postuluje się opracowanie w szkołach swoich wielokulturowych tradycji, szkoły powinny stworzyć miejsca wielokulturowych spotkań. Autorzy zauważają rosnącą alienację ludzi obcego pochodzenia, których religia i tradycje nie znajdują poparcia ze strony państwa. Powoduje to jeszcze większe umocnienie się tradycji etnicznych i religijnych w sposób, który uniemożliwia integrację. Ten fakt wydaje się czynnikiem przynaglającym szkoły do szukania odpowiedzi i praktyki wychowawczej wychodzących naprzeciw tym zjawiskom. Na gruncie wychowania i edukacji szkolnej panuje jednak przekonanie, że szkoły prywatne wyznaniowe lub niezależne etniczne mają pewien określony profil, który sprzyja atmosferze integracji, jednak brak kontaktu z dziećmi o innej tradycji i wartościowaniu niż własne nie sprzyja tożsamości dzieci, która najlepiej odpowiada założeniom demokratycznym. Uważa się, że szkoły te

44 Enkvist Inger, Feltänkt. En kritisk granskning av idebakgrunden till svensk ulbildningspolitik, Kristianstad Boktryckeri AB, Kristianstad 2001, s. 31-32.

45 I. Enkvist, Feläntk, En kritisk granskning av idebakgrunden till svens utbilningspolitik, Boktryckeri AB, Kristianstad 2001, s. 138-141; I. Enkvist, Uppfostran och utbildning, WS Bookwell, Finland 2007, s. 9-10. 
nawet mogą być pewnym zagrożeniem dla demokracji, odtwarzając dawne wartości i struktury władzy ${ }^{46}$.

Wychowanie nie może funkcjonować w próżni etycznej i dlatego dochodzi do paradoksu, w którym o wartościach etycznych nie decydują obiektywne kryteria potwierdzane przez obiektywne badania naukowe w zakresie etyki, lecz kryteria te ustala Narodowa Agencja Edukacji, publikując listę konkretnych wskazań, umożliwiających kontrolę i odpowiedź na pytanie: czy określone wartości värdegrund są aktualnym fundamentem etycznym życia danej szkoły? Podkreśla się bardzo mocno w tych zaleceniach potrzebę wychowania, które powinno prowadzić do przyjęcia i dzielenia tych wspólnych fundamentalnych wartości ustalonych w ten sposób na zasadzie urzędowego zarządzenia ${ }^{47}$. Z drugiej strony, paradoksalnie, program nauczania dla szkół podstawowych z roku 1962 zagadnienia etyczne umieszcza w ramach lekcji religii, która przecież powinna podawać wartości i etykę opartą na podstawach silniejszych niż dyrektywy jakiejś agendy rządowej8.

\section{BRAK ETYKI OPARTEJ NA PRAWIE NATURALNYM - NIEBEZPIECZEŃSTWO FUNDAMENTALIZMU}

O wychowawczych zadaniach szkoły w odniesieniu do wpajania wartości mówi także dokument odnoszący się do treści nauczania i kryteriów klasyfikacji z 1994 roku. Potwierdza się w nim wychowanie oparte na nienaruszalnej wartości ludzkiego życia, wolności osobistej,

46 G. Zackari, F. Modigh, Värde grunds boken - om samtal för demokrati i skolan, AB DanagĆrds Grafiska, Stockholm 2000, s. 68-70, 72-73.

47 Skolverket, Demokratie och värdegrund, 2005. Skolverket, Education Act. Democracy and Fundamental Values, 2001, paragraf 2f. tego dokumentu mówi, że jedną z dróg prowadzących zwłaszcza do uniknięcia przestępstw związanych z nieprzestrzeganiem równości płci jest wymaganie, aby podręczniki szkolne były aprobowane przez reprezentację kobiet, które były dotknięte tego typu przestępstwem; W. Alberts, Integrative religious education in Europe, Berlin 2007, s. 217-218.

48 Läroplan för grunskolan, Skolvöverstyrelsen 1962, s. 217-225. 
równej godności ludzi, równości kobiet i mężczyzn oraz solidarności ${ }^{49}$. Wspomniane już deklaracyjne nawiązanie w programie szkolnym do etyki, która ma swoje korzenie w chrześcijaństwie i zachodnim humanizmie, w praktyce wychowawczej szkoły nie znajduje potwierdzenia. Jakiejkolwiek etyce religijnej zarzucano, że osłabia pozycję człowieka względem Boga. Bardzo łatwo przy tym pomija się fakt, że etyka chrześcijańska jest oparta na prawie naturalnym, które jest niezależne od religii. W tradycji katolickiej prawo naturalne jest znane jako boskie, wieczne i uniwersalne. Piltz wyraża słuszną opinię w tym względzie, twierdząc, że różnica i napięcia zasadnicze, które mają skutki także w teorii i praktyce wychowawczej, nie są powodowane konfliktem prawa naturalnego z prawem boskim, lecz ich przyczyną jest przyjęta wcześniej idea humanizmu, wg którego człowiek jest panem siebie i nie do pomyślenia jest, aby odwoływał się w ustaleniach etycznych do jakiegokolwiek innego podmiotu niż własny ${ }^{50}$. Dzięki temu, że bazą etyki chrześcijańskiej jest prawo naturalne, nie trzeba być chrześcijaninem, aby przyjąć etykę człowieka wprowadzoną najpierw przez chrześcijaństwo, gdyż dotyczy ona wszystkich ludzi niezależnie od wyznawanej religii i światopoglądu. Etyka ta jest dostępna dla każdego. Piltz, ukazując jak starożytność przez filozofię, literaturę i sztukę dochodziła do określenia podstawowych fundamentów etycznych, zaznacza, że cnoty, która jest wynikiem życia zgodnego z zasadami etyki, nie osiąga się bez wysiłku i pracy człowieka. Postępowanie moralne jest czymś więcej niż tylko zbiorem zasad w głowie, musi ono być niejako wytrenowane, aby stało się wzorem dla spontanicznych, właściwych etycznie reakcji. Proces do tego prowadzący nazywamy wychowywaniem człowieka. Tę zasadę Piltz rozpoznaje już u stoików, którzy w opozycji do człowieka dojrzałego i spokojnego, wychowanego, ukazują brutalnego barbarzyńcę. Piltz, idąc za tą myślą filozofów, stwierdza, że wychowywane powinny być całe narody.

49 Grundskolan, Kursplaner och betygskriterier, Skolverket och Fritzes, Graphium Västra Aros, VästerĆs 2000, s. 6.

50 A. Piltz, Kristen etik och västerländsk humanism, w: Statens offentliga utredningar, 1992: 94, Skola för bildning, Stockholm, Norstedts Tryckeri AB 1992, s. 437-438. 
W myśli tej widoczny jest bezpośredni związek wychowania z etyką. Bez etyki i wychowania ludzkość i natura ludzka może być pozostawiona odłogiem i nieużytkowana, nieuprawiana ${ }^{51}$. Brak przyjęcia tej perspektywy etycznej, wychowawczej i kulturowej zdaniem Piltza spowodowany jest fundamentalizmem, w który popada nie chrześcijaństwo ze swoją etyką, lecz tzw. współczesny, nowoczesny świat, który uważa, że dobro i zło nie może mieć innego znaczenia niż to, które dane społeczeństwo określa poprzez swoje prawa, kulturę i modę. Poza tym schematem, że coś może być zgodne lub nie z prawem, dobro i zło są bezsensowne. Jest to tzw. pozytywizm prawny. Obok niego istnieje też pozytywizm religijny, który mówi, że Bóg nie ustanowił prawa, ponieważ jest ono słuszne, lecz dlatego jest słuszne ponieważ Bóg w swej niezgłębionej mądrości je ustanowił. Etyka w takim ujęciu byłaby tylko przedmiotem wiary. Wynikałaby jedynie z samowoli Boga, który tak, a nie inaczej postanowił. Przyjęcie tej etyki nie byłoby przyjęciem prawa jako mądrości, miłosierdzia jako najlepszego dla człowieka, lecz akt przyjęcia prawa etycznego byłby wyrazem lojalności ze strony człowieka wobec Boga. Byłby to swego rodzaju zestaw testowy, z którym człowiek musi się pogodzić, jeśli chce się zachować dobrze. Z drugiej strony, jeśli dany człowiek nie byłby wierzący, nie mógłby działać etycznie. Tak samo niewierząca osoba nie byłaby zobowiązana do przestrzegania takich samych zasad moralnych jak wierzący. Konsekwentnie jeśli etyka chrześcijańska oparta jest jedynie na przesłankach wynikających z wiary, nie mogłaby być podstawą do edukacji szkolnej w pluralistycznym społeczeństwie. Właśnie takie rozumienie zasad etyki chrześcijańskiej jest formą współczesnego fundamentalizmu, w który popadają bardzo często ci, którzy pod adresem chrześcijan kierują takie zarzuty. Anders Piltz przytacza tutaj szereg przykładów z literatury, prasy i kultury w Szwecji ${ }^{2}$. Ponadto ukazuje nowość Ewangelii, która nie podaje żadnego nowego nakazu. Nowością jest to, że Jezus Chrystus ukazuje jak żyć etyką, kieruje uwagę do wnętrza osoby, a nie na zewnątrz. Każdemu systemowi regulacyjnemu grozi niebezpieczeństwo legalizmu. Wewnątrz etycznej

\footnotetext{
51 Tamże, s. 440-443.

52 Tamże, s. 443-444.
} 
propozycji chrześcijańskiej stoi nie przepis, zasada, kanon, lecz osoba Jezusa Chrystusa z przykazaniem miłości, także do wrogów. To związek z Chrystusem decyduje o etyce, a zewnętrzny sukces nie może być kryterium wartości moralności prywatnej, jak i etyki społecznej. Etyka Ewangelii nie staje się nowym prawem, lecz może być przyjęta jedynie w wierze, nadziei i miłości na wzór Chrystusa. Jak każda forma miłości jest poza zakresem przepisów, jurysdykcji i komisji. Co konkretnie oznacza etyka chrześcijańska jest widoczne nie w księgach, lecz przede wszystkim w ludziach, zarówno tych na co dzień niezauważanych, jak i w kanonizowanych świętych naśladujących Chrystusa. To oni zmieniają świat od wewnątrz ${ }^{53}$. Ostatecznie jednak należy stwierdzić, że przynajmniej w warstwie programowych ustaleń narodowe programy nauczania w Szwecji zawierają sformułowania odwołujące się do ich zgodności z zasadami etyki chrześcijańskiej i zachodniego humanizmu. Wprowadzono je jednak po długich debatach prowadzonych przez różne gremia ${ }^{54}$.

\section{Podsumowanie}

Zadaniem niniejszego artykułu było syntetyczne przedstawienie głównych linii współczesnej dyskusji na temat bezpieczeństwa wychowania i edukacji w Szwecji. Omówienie tak rozległej tematyki w ramach jednego artykułu charakteryzuje się pewną ściśle określoną aspektowością oraz koniecznym zawężeniem omawianych zagadnień. Podstawowe wnioski, jakie się nasuwają, pozwalają stwierdzić, że współczesna mobilność ludzi i odczuwany pluralizm kulturowy nie mogą stanowić przesłanki do rezygnacji z budowania religijnej i narodowej świadomości historycznej w ramach wychowania i edukacji. Odnosi się to

53 Tamże, s. 446-449.

54 Utbildningsdepartament, Curriculum for the Non-Compulsory School System, (Lpf 94,5) 1994; K. Borevi, Religion i skolan, w: P. Karlson, I. Svanberg, Rligionsfrihet i Sverige, wyd. Studentlitteratur, Lund 1997, s. 37-69; H. Sven, Hur religionsämnet formades, w: A. Edgar, Furenhead Ragnar, Livstolkning och värdegund: att undrvisa om religio, livsfĆgor och etic, Liköpings Universitet 2000, s. 212-251; M. W. Alberts, dz. cyt., s. 217-218. 
zarówno do realiów Szwecji, jak i Polski. Człowiek do swojego rozwoju potrzebuje nie tylko światła nieograniczanej wiedzy, lecz także ma potrzebę zadomowienia, bycia u siebie - horyzontu ograniczonego do rzeczy sobie bliskich i znanych, zakorzenienia w trwałych dobrach tradycji religijnej i narodowej. Zwłaszcza w tych ostatnich zawarte są konieczne do sensownego życia tzw. punkty orientacyjne, które strzegą tzw. dobrych wartości. Edukacja, jeśli jest skupiona jedynie na wiedzy i dynamizmach działania, łatwo gubi potrzebę studium historii.

Powszechnie dzisiaj kładzie się nacisk na wartości komunikacyjne i działaniowe. Jednak bez wiedzy historycznej istnieje realne niebezpieczeństwo uwiedzenia całych grup ludzi przez różnego rodzaju ideologie. Grozi to nawet upadkiem demokracji. Życie we współczesnej internacjonalnej rzeczywistości wymaga znajomości języków obcych (najczęściej jest to język angielski), jednak sama możliwość komunikacji w obcym języku bez wspólnej koncepcji dobra nie spowoduje, że relacje międzyosobowe i międzynarodowe będą się charakteryzowały pokojem, demokracją, solidarnością i równością. Wychowanie i edukacja domagają się formacji i ćwiczeń etycznych, gdyż tylko w ten sposób można wytworzyć między osobami wspólną platformę etyczną, konieczną do działania moralnego. Współczesny system wychowania i edukacji w Szwecji, a także w wielu innych krajach, skażony jest swego rodzaju fundamentalizmem tzw. nowoczesnego świata, który w ustaleniach etycznych nie chce odwoływać się do innego podmiotu niż własne ja osoby. Konsekwencją takiej postawy jest odrzucenie w wychowaniu i edukacji etyki chrześcijańskiej - błędnie głosząc przy tym, że do jej zaakceptowania potrzeba wiary. W ten sposób niebezpiecznie neguje się uniwersalność podstaw prawa naturalnego, ujmując je jedynie jako partykularne zasady chrześcijańskie. Anders Piltz takie przekonanie określa mianem fundamentalizmu nowoczesnego świata, który nie dostrzega prawdy, że aby uznać etyczne uniwersalne prawo naturalne, nie trzeba być chrześcijaninem. 


\section{Summary}

SAFETy UPBRinging AND EDUCATION IN SwEDEN AND ETHICS

This article is an attempt to highlight the main areas of general Swedish pedagogical issues in the context of building a secure basis of upbringing and education. Fidelity to the democratic values seems to be the most basic guarantee of safe upbringing and education. Interculturalism, tolerance, internationality promoted in the educational system at all levels to protect democracy and in which values to educate citizens. However, more often recognizes that without a clearly defined ethical upbringing and education system is not completely safe and does not sufficiently protect democratic values. There is a need for the security of the democratic system and also for the sake of upbringing and education, the adoption of ethical categories. They are primary to the original democratic values. Ethics based on the natural law defines good and evil in a more credible than do the community through its culture, fashion and law. Closing the ethics results as an fundamentalism which often falls in the modern world. This trend is particularly dangerous for the sphere of education and upbringing of the young generation. 